\title{
275. 乳がんの接線照射における補償フィルタの検討

\author{
compensating filters in tangential field of breast cancer
}

\author{
愛知県がんセンター放射線治療部 ○水谷武雄 内山幸男 \\ (takeo,mizutani) (jukio,uchiyama)
}

《目的》 乳がんの温存照射について、当施設では、原体照射装置の多段さリメータ用いた接線 照射および多目的りエッギなどの開発を進め、第45.47回日本放射線技術学会の総会で報告を

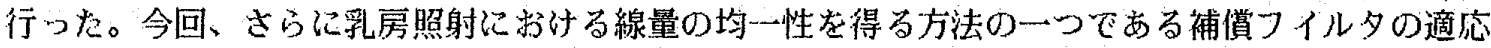
について検討を行い良い結果が得られたので報告する。

《方法》補償つイル夕注、私共が日常業務で使用し、放射線治療用補償つイル夕の製作に応用し ている、モアレ像撮影装置（FM-3011）（富上写真工機社製）を用いた。線量分布の計算流、市販 の治療計画用コンピュータ（modulex）（CMS社製）で計算した。補償効果の線量測定に法、态 用技研の AE-132a (0.6cc) を用いた。補偵つイル夕の材筫は3mm厚のアクリルを使用した。

《結果》，乳がんの接線照射は、6MVのX線を用い、ウェッヂフイル夕により線墨の均一性を得 ることを目的に使用している。しかし、線量分布图を多段コりメー夕每に抽出し三次元の線量評価 失した時、5〜15\%の高線量域が確認され。我々が開発した多目的ウエッヂに扔いても全て满足 さ机ていなく使用の限界も生じた。より適切な線量分布は、モア 上像を用いて補償つイル夕を作成することで達成さ狆な。日常に 用いているモアレ像撮影装置は、正面及び側面から撮影が可能な 機構でった。今回、乳房の接線照射に书いて線束斜入射方向加 ら撮影が出来るよう撮影装置の改造を行った。リニアック照射室 の治療宴台上で治療体位を設定し、即モアレ像を撮影可能とした。 接線からの線束入射方向（前方斜と後方斜）て撮影したもアレ 等高線像を图一 1 に示した。このモアレ等高線像を補償フイルタ の寸法に合うように搪大する。この形に沿って補償コイル夕用の

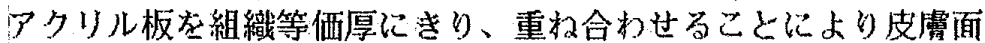
の凹凸に态じた補償フイル夕が完成する。乳房照射の補僧フイル タをりニアックの照射口下に取り付计た実況を图一2に示した。 《まとめ》乳房温存照射は、近年增加の傾向が世界的に見られ 理想的且つ最良の照射方法が期待されている。れ视線量の均 一性と毎日の照射の再現性そして簡単な照射法肪良い（文献 1 ）。

日常業務の中で、容易に得られ当補償フイル夕在用いることで 图一-3のように三次元の線量分布の均一化淂られている。
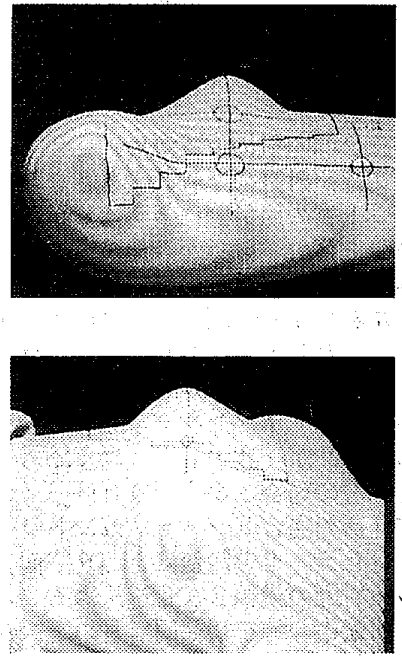

図-1 モアレ等高線像

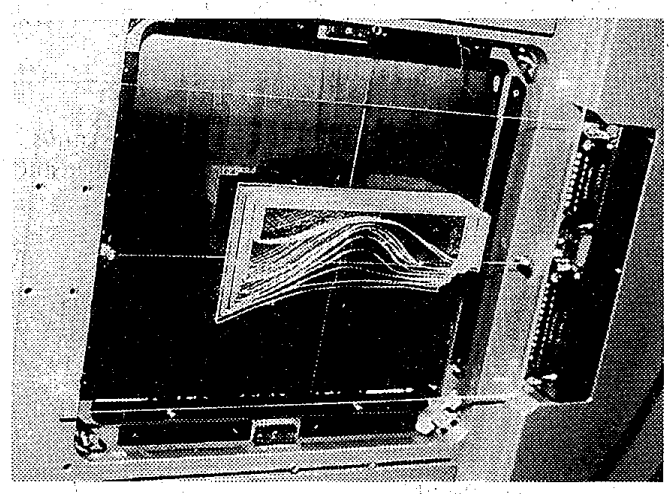

図一2 师アッ紧照射口下の補償フ似

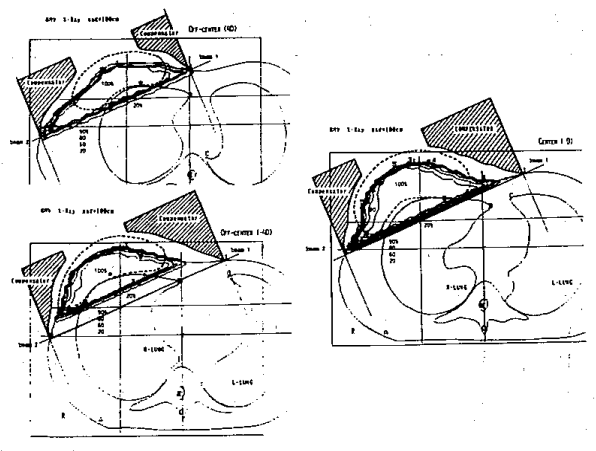

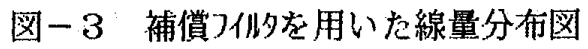

《文献》 水谷武雄 他: 多段了リメ-夕を用いた照射法 日放腫会誌suppl-241-243 1991 